Tropical Journal of Pharmaceutical Research September 2015; 14 (9): 1621-1628

ISSN: 1596-5996 (print); 1596-9827 (electronic)

(C) Pharmacotherapy Group, Faculty of Pharmacy, University of Benin, Benin City, 300001 Nigeria.

All rights reserved.

Available online at http://www.tjpr.org

Original Research Article

http://dx.doi.org/10.4314/tjpr.v14i9.11

\title{
Hypolipidemic Activity of Prosopis cineraria L (Druce) Fruit Extract and Molecular Modeling Study with Farnesoid X Receptor (FXR)
}

\author{
Pankaj G Jain* and Sanjay J Surana \\ R.C. Patel Institute of Pharmaceutical Education and Research, Shirpur, Dist. -Dhule- 425405, (MS) India
}

*For correspondence: Email: pgjain@yahoo.com; Tel: +91-9823668845

Received: 27 December 2014

Revised accepted: 20 June 2015

\begin{abstract}
Purpose: To investigate the hypolipidemic potential of the $70 \%$ ethanol fruit extract of Prosopis cineraria (Fabaceae) (Et. PCF) in triton-induced hyperlipidemia in rats.

Methods: Et-PCF was obtained by pulverizing whole dried fruits and extracting with $70 \%$ ethanol. Adult Sprague Dawley rats were divided into six groups of six rats each. The groups were namely normal control, hyperlipidaemic control, standard drug-treated (simvastatin $4 \mathrm{mg} / \mathrm{kg}$ ), and three Et-PCF (200, 400 and $600 \mathrm{mg} / \mathrm{kg}$, respectively)-treated groups. Apart from normal control, all other groups received a single dose of triton (200 mg/kg, i.p.) exactly $30 \mathrm{~min}$ after a dose of the standard drug and Et-PCF for the induction of hyperlipidemia. Twenty four hours after triton injection, hyperlipidemia was confirmed by collecting blood samples from all the rats and testing for serum lipid profile. Antioxidant activity, in the form of inhibition of lipid peroxidation, was determined along with chromatographic analysis. Moreover, molecular docking study of $\beta$-sitosterol (active constitute of PCF) was performed with Farnesoid $X$ receptor.

Results: Triton-induced hyperlipidemia group showed significant increase in total cholesterol, low density lipoprotein cholesterol (LDL), very low density lipoprotein cholesterol (VLDL), triglyceride, atherogenic index and decreased high density lipoprotein cholesterol (HDL), compared to normal control group. Et-PCF treated groups showed reduction in serum cholesterol, triglyceride, VLDL and LDL levels compared to triton treated control group. Extract at the dose of $200 \mathrm{mg} / \mathrm{kg}$ significantly reduce serum cholesterol $(p<0.01)$ and serum $L D L(p<0.01)$. At the dose level of $400 \mathrm{mg} / \mathrm{kg}$ and 600 $\mathrm{mg} / \mathrm{kg}$ extract is effective to significantly reduce serum cholesterol $(p<0.05)$, triglyceride $(p<0.05)$, VLDL $(p<0.05)$, LDL $(p<0.05)$ and atherogenic index $(p<0.05)$ and these results are almost equivalent to those of standard drug simvastatin. Furthermore, antioxidant activity, i.e., IC 50 of Et-PCF was $58.33 \mu \mathrm{g} / \mathrm{ml}$. Molecular docking score of $\beta$-sitosterol for Farnesoid $X$ receptor was $-8.32 \mathrm{kcal} / \mathrm{mol}$, suggesting excellent binding conformation of Et-PCF to receptor molecules.

Conclusion: The findings suggest that Prosopis cineraria may be beneficial for preventing hyperlipidaemic complications by its anti-hyperlipidemic and antioxidant activities.
\end{abstract}

Keywords: Prosopis cineraria, Anti-hyperlipidemic activity, Simvastatin, Triton, Docking studies, Farnesoid $X$ receptor

Tropical Journal of Pharmaceutical Research is indexed by Science Citation Index (SciSearch), Scopus, International Pharmaceutical Abstract, Chemical Abstracts, Embase, Index Copernicus, EBSCO, African Index Medicus, JournalSeek, Journal Citation Reports/Science Edition, Directory of Open Access Journals (DOAJ), African Journal Online, Bioline International, Open-J-Gate and Pharmacy Abstracts

\section{INTRODUCTION}

Hypercholesterolemia is an excessive high plasma cholesterol level and a strong risk factor for negative cardiovascular events such as obesity, diabetes and hypertension [1,2]. Atherogenesis is a multifactor process that 
includes oxidative modification of LDL which further leads to atherosclerosis [3].

Research, in recent years, has focused on dietary antioxidants from plant-derived sources to normalize elevated levels of cholesterol atherogenous fractions, mainly LDL, and of glucose in an attempt to reduce the cardiovascular risk [4,5]. Hyperlipidemia is a clinical condition characterized by elevation in blood lipid levels. Increase in blood lipid levels stimulates atherosclerosis and leads to hardening of arteries. This hampers normal blood circulation and results in fatal cardiovascular disease (CVD) [6].

A logical strategy to prevent or treat atherosclerosis and reduce the incidence of cardiovascular disease events is to target hyperlipidaemia and oxidative stress by diet and/or drug intervention. Therefore, there is an urgent need to have drugs with lipid lowering and antioxidant activities with no side effects. Previously conducted studies demonstrated natural products derived from different parts of various plants possess significant hypolipidemic potential [7-10].

Prosopis cineraria, a plant belonging to the family Fabaceae), is known as 'Khejri' in many parts of India. It is used as a therapeutic agent in greater parts of India, Burma and Sri Lanka [11]. Literature suggests that, the bark is used in the treatment of asthma, bronchitis, dysentery, leucoderma, leprosy, muscle tremors and piles $[12,13]$. Several bioactive compounds such as flavonoids, alkaloids, phenolic contents, free amino acids, spicigerin, prosogerin $A, B, C$ and $D, \beta$-sitosterol and vitamins have been isolated from different parts of the plant $[14,15]$. The presence of these bioactive compounds suggest Prosopis cineraria may possess hypolipidemic and antioxidant potentials like other previously studied medicinal plants [7-10]. Fruits of Prosopis cineraria are an important constituent of the diet of tribal people from Satpuda region of Maharashtra, India and these people are free from cardiovascular complaints.

Hence, we hypothesized that oral treatment with Prosopis cineraria fruits extract probably possesses hypolipidemic effect in triton-induced hyperlipidemia. As the antioxidant from plant derived sources help to reduce elevated levels of cholesterol $[4,5]$, we also investigated the antioxidant potential of Et-PCF. Docking study of $\beta$-sitosterol for FXR was undertaken by in-silico to evaluate binding conformation of Et-PCF to receptor molecules [16].

\section{EXPERIMENTAL}

\section{Animals}

Sprague Dawley rats (180-200 g) of either sex were obtained from college animal house of R.C. Patel Institute of Pharmaceutical Education and Research (RCPIPER), Shirpur, India. They were housed under standard laboratory conditions and were fed commercial rat feed (Lipton India Ltd., Mumbai, India) and previously boiled water allowed to cool, ad libitum. Purpose of using boiled water was to maintain strict hygienic conditions and avoid chances of infection. The experimental protocol was approved by IAEC and CPCSEA, Department of forest and environment, Government of India, New Delhi (RCPIPER/IAEC/2012-18/20 with reg no. 651/02/C/CPCSEA).

\section{Chemicals}

Triton WR 1339 (Loba- chemie Ltd, India), cholesterol, triglyceride, HDL kits (BEACON Diagnostic Pvt. Ltd, Gujarat, India), ethanol procured from college central store (RCPIPER) were used in this study. All the solvents used were analytical reagent $A R$ and high performance liquid chromatography (HPLC) grade.

\section{Preparation of Prosopis cineraria extract}

The plant material was collected between 8.0010.00 AM in the month of July-2013 at Satpuda region, Maharastra, India. Authentication was made by Professor Dr. L. K. Kshirsagar, Taxonomist, Department of Botany, S.S.V.P.S's L. K. Dr. Ghogre Science College, Dhule, North Maharashtra University, Jalgaon. A voucher specimen (RCPIPER/Pharmacology/25-2013) has been kept in the Department of Pharmacology of Institute for further reference. Fruits were separated, cleaned, washed and airdried. The dried fruits were pulverized by passing through 40 mesh sieve and extracted with $70 \%$ ethanol using a Soxhlet extractor. The extract was concentrated in vacuum evaporator below $40^{\circ} \mathrm{C}$.

\section{Phytochemical investigation chromatographic analysis of extract}

and

The ethanol extract was subjected to various tests for various phytochemical constituents as previously described by Kokate [17]. High performance liquid chromatography (HPLC) analyses was carried out on the extract using Shimadzu class LC-10AT HPLC system, equipted with Rheodyne $7725 \mathrm{i}$ injector fitted with 
a $20 \mu$ loop, column oven, and a photodiode array (PDA) detector, using Column Exsil ODS C-18 column $(250 \mathrm{~mm} \times 4.6 \mathrm{~mm})$. The results were analyzed by chromquest version 3.0 software on Pentium computer (Hewlett Packard). Samples were eluted in Acetonitrile:water $(90: 10)$ as the mobile phase. Flow rate was constantly kept at $0.3 \mathrm{ml} / \mathrm{min}$. and detection was carried out at $210 \mathrm{~nm}$.

\section{Acute oral toxicity study}

Albino female mice weighing 25-30 g were used for acute oral toxicity study. Acute toxicity study was carried out as per Organization for Economic Co-operation and Development (OECD) Guideline 425 "Up \& Down" method [18]. The test drug was found to be safe up to the dose of $5000 \mathrm{mg} / \mathrm{kg}$ body weight hence 1/10th of this dose was taken as an effective dose (500 $\mathrm{mg} / \mathrm{kg}$ ). The doses selected were 200, 400 and $600 \mathrm{mg} / \mathrm{kg}$.

\section{Assessment of hypolipidemic activity}

Sprague Dawley rats were selected for the experimental model. The rats were fed with the standard diet and water ad libitum before the experiment. Room temperature was maintained between 20 and $30{ }^{\circ} \mathrm{C}$ and relative humidity of 40 - $60 \%$. The weight of the selected rats was between 180 and $200 \mathrm{~g} .36$ rats were divided into 6 groups of 6 rats per group. According to the body weight of individual rat, $200 \mathrm{mg} / \mathrm{kg}$ of triton was injected intraperitoneally [19].

Group 1 - Normal saline $1 \mathrm{ml}$ orally/animal.

Group 2 - Triton WR 1339 (200 mg/kg)

Group 3 - Triton WR 1339 (200 mg/kg) + Simvastatin $4 \mathrm{mg} / \mathrm{kg}$ orally

Group 4 - Triton WR 1339 (200 mg/kg) + Et-PCF $200 \mathrm{mg} / \mathrm{kg}$ orally

Group 5 - Triton WR 1339 (200 mg/kg) + Et-PCF $400 \mathrm{mg} / \mathrm{kg}$ orally

Group 6 - Triton WR 1339 (200 mg/kg) + Et-PCF $600 \mathrm{mg} / \mathrm{kg}$ orally

Blood samples were collected from normal rats and taken for analysis. For the treatment groups, the extract/simvastatin was given orally $30 \mathrm{~min}$ prior to triton injection. $3 \mathrm{ml}$ of blood sample was collected from all the rats by making retro-orbital puncture both before triton injection $(0 h)$ and after triton injection (24 h) [7]. Blood serum was separated by centrifugation at $3000 \mathrm{rpm}$ and analyzed for lipid profile.

\section{Determination of LDL cholesterol and atherogenic index}

LDL cholesterol (LDLC) was calculated as in Eq 1 [20].

$\mathrm{LDLC}=\mathrm{TC}-\mathrm{HDLC}-\mathrm{VLDL}$

where TC, HDLC and VLDL are total cholesterol, HDL cholesterol and VLDL cholesterol, respectively.

Atherogenic index (Al) was computed as in $\mathrm{Eq} 2$ [21].

$A I=\{(T C-H D L C) / H D L C\}$

\section{Evaluation of antioxidant activity}

\section{Anti-lipid peroxidation}

The mixture containing $0.5 \mathrm{ml}$ of rat liver homogenate, $1 \mathrm{ml}$ of $0.15 \mathrm{ml}$ potassium chloride $(\mathrm{KCl})$ and $0.5 \mathrm{ml}$ of different concentrations (20 $\%, 40 \%, 60 \%, 80 \%, 100 \%)$ of drug extract were prepared. Lipid peroxidation was initiated by adding $100 \mu \mathrm{l}$ of $1 \mathrm{mM}$ ferric chloride. The reaction mixture was incubated for $30 \mathrm{~min}$ at 37 ${ }^{\circ} \mathrm{C}$. After incubation $2 \mathrm{ml}$ of ice-cold $0.25 \mathrm{~N}$ Hydrochloric acid $(\mathrm{HCl})$ containing $15 \%$ trichloroacetic acid (TCA) and $0.38 \%$ thiobarbituric acid (TBA) and $0.2 \mathrm{ml}$ of $0.05 \%$ butylated hydroxytoluene (BHT) was added in the reaction mixture. This reaction mixture was heated for $60 \mathrm{~min}$ at $80{ }^{\circ} \mathrm{C}$, cooled and centrifuged at $5000 \mathrm{~g}$ for $15 \mathrm{~min}$. The absorbance of the supernatant was measured spectrophotometrically (Microplate reader power wave XS2, BIOTEK, USA) at $532 \mathrm{~nm}$ against a blank, which contained all reagents except liver homogenate and drug. Identical experiments were performed to determine the normal (without drug and ferric chloride) and induced (without drug) lipid peroxidation levels in the tissue. Percent anti-lipid peroxidation effect (ALP) was calculated as in Eq 3 [8].

$\operatorname{ALP}(\%)=\{(\mathrm{Af}-\mathrm{As}) / \mathrm{Af}-\mathrm{An}\} 100$

where Af, As and An are the absorbance of ferric chloride, test sample and normal sample, respectively.

\section{Reducing power assay}

The reducing power of the ethanolic extract of Prosopis cineraria was determined on the ability 
of antioxidants to form colored complex with potassium ferricyanide. Various concentrations of the extract $(10,20,40,60$ and $80 \mu \mathrm{g} / \mathrm{mL})$ were mixed with $2.5 \mathrm{~mL}$ phosphate buffer $(\mathrm{pH} 6.6)$ and $2.5 \mathrm{~mL}$ potassium ferricyanide $(1 \%)$. The mixture was incubated at $50{ }^{\circ} \mathrm{C}$ for $20 \mathrm{~min}$. $2.5 \mathrm{~mL}$ TCA $(10 \%)$ was added to it and centrifuged at 3000 rpm for $10 \mathrm{~min}$. The supernatant $(2.5 \mathrm{~mL})$ was mixed with $2.5 \mathrm{~mL}$ of water and $0.5 \mathrm{~mL}$ of $\mathrm{FeCl}_{3}$ $(0.1 \%)$ were added to it, and the absorbance was measured spectrophotometrically at $700 \mathrm{~nm}$. Increased absorbance of the reaction mixture indicates increased reducing power [22].

\section{Molecular docking study}

The molecular docking tool, GLIDE (Schordinger Inc, USA, 2009), was used for ligand docking studies into the FXR binding pocket. The crystal structures of FXR was obtained from protein data bank (PDB ID: 1OSH) [23]. The protein preparation was carried out using 'protein preparation wizard' in Maestro 9.0 in two steps, preparation and refinement. After ensuring chemical correctness, water molecules in the crystal structures were deleted and hydrogens were added, where they were missing. Using OPLS 2005 force field energy of crystal structure was minimized [24]. This is forcefield in Schordinger 9.0, which is used to optimize the geometry of protein crystal structure and beta sitosterol. After optimization, we docked beta sitosterol into the cavity of FXR to check the binding mode.

Grids were defined centering them on the ligand in the crystal structure using the default box size. The ligands were built using maestro build panel and prepared by Ligprep 2.2 module which produce the low energy conformer of ligands using OPLS 2005 force field. The low energy conformation of the ligands was selected and was docked into the grid generated from protein structures using standard precision (SP) docking mode. The final evaluation is done with glide score (docking score) and single best pose is generated as the output for particular ligand.

\section{Statistical analysis}

The data are presented as mean \pm standard error of mean (SEM). All data were analyzed using one-way analysis of variance (ANOVA) with Dunnet's post hoc test by Graph Pad Prism 5 . Differences were considered significant at $p<$ 0.05 .

\section{RESULTS}

The ethanol extract tested positive for flavonoids, tannins, saponins, sterols and phenolic compounds. HPLC analysis also confirmed the presence of these phytoconstituents. The HPLC chromatogram of the extract is shown in Fig 1. The HPLC finger print for standard $\beta$-sitosterol showed a single peak while the extract showed six peaks at the wavelength of $210 \mathrm{~nm}$.

\section{In vivo hypolipidemic effect of Et-PCF on lipid profile}

The effect of Et-PCF on serum lipid profile in control and treatment groups at different doses are shown in Table 1. The acute injection of TWR caused a significant increase in lipid levels when compared with Group I rats. Group VI showed a significant $(p<0.01)$ reduction in cholesterol (26.67\%), triglyceride (26.52\%), LDL $(54.93 \%)$ and VLDL $(26.60 \%)$ levels, where as significant increase $(p<0.05)$ was observed in HDL $(11.53 \%)$ after treatment of Et-PCF when compared to Group II.
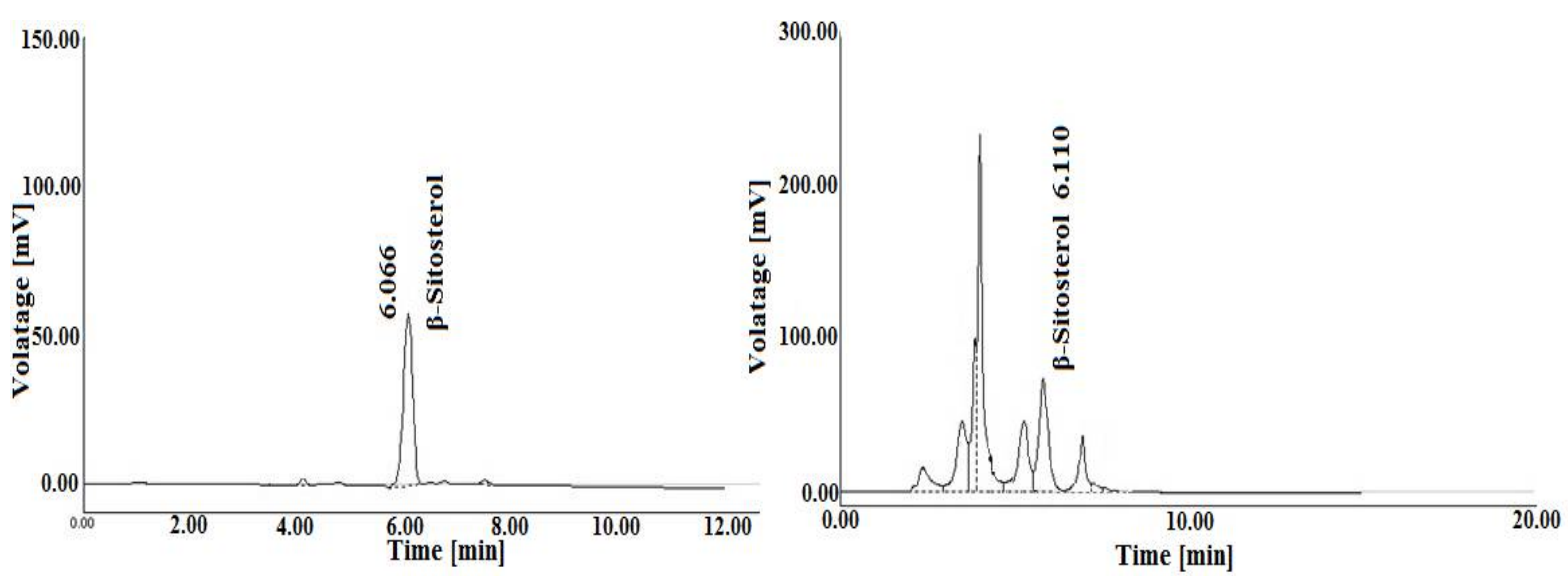

Fig. 1: HPLC fingerprint of ethanolic extract of Prosopis cineraria 
The Al was also significantly $(p<0.01)$ decreased (53.34 \%) in Group VI after treatment. In group IV at the minimum dose of $200 \mathrm{mg} / \mathrm{kg}$ Et-PCF significantly reduce both serum cholesterol $(p<0.01)$ and serum LDL $(p<0.01)$ as compared to group II. We observed a dosedependent reduction of lipid profile and maximum antihyperlipidemic effect $(p<0.01)$ was seen in Group V (400 mg/kg of Et-PCF) and VI (600 $\mathrm{mg} / \mathrm{kg}$ of Et-PCF) when compared to Group II. This effect of reduction in lipid profile and maximum antihyperlipidemic effect is almost equivalent to group III who received standard drug simvastatin $(p<0.01)$.

\section{Antioxidant activity}

In the present study, the ethanol extract showed potent inhibition of lipid peroxidation induced by Iron/ADP/Ascorbate complex in rat liver homogenate, $\mathrm{IC}_{50}$ value was $58.33 \mu \mathrm{g} / \mathrm{ml}$. It showed dose dependent inhibition of lipid peroxidation. Standard ascorbic acid showed $\mathrm{IC}_{50}$ of $50.92 \mu \mathrm{g} / \mathrm{mL}$ (Fig 2).
The measurement of reductive ability was done by $\mathrm{Fe}^{3+}-\mathrm{Fe}^{2+}$ transformation in the presence of ethanol extract and standard antioxidant, ascorbic acid [25]. The reducing power is associated with antioxidant activity. As shown in Fig. 3, the ethanolic extract showed a reducing power comparable with the standard at the highest concentration i.e. at $80 \mu \mathrm{g} / \mathrm{ml}$.

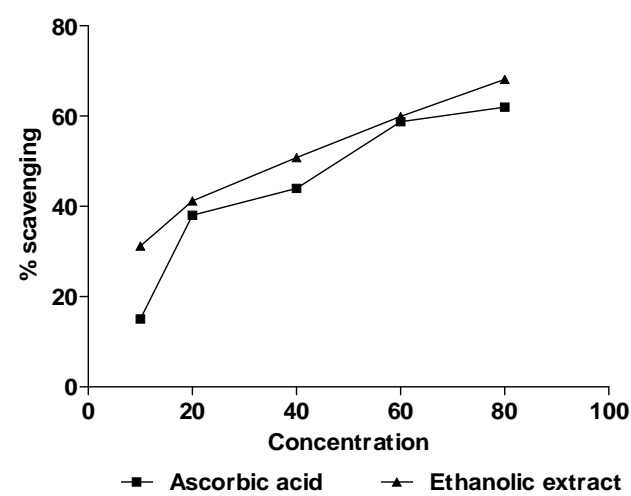

Fig 2: Effect of Prosopis cineraria on lipid peroxidation activity in rat liver homogenate

Table 1: Effect of the ethanolic extract of Prosopis cineraria on the lipid profile of triton induced hyperlipidemia

\begin{tabular}{|c|c|c|c|c|c|c|}
\hline $\begin{array}{l}\text { Group } \\
\text { (mg/kg dose) }\end{array}$ & $\begin{array}{c}\text { Cholesterol } \\
\text { level } \\
(\mathrm{mg} / \mathrm{dl})\end{array}$ & $\begin{array}{c}\text { Triglyceride } \\
\text { level } \\
\text { (mg/dl) }\end{array}$ & $\begin{array}{c}\text { VLDL } \\
\text { level (mg/dl) }\end{array}$ & $\begin{array}{c}\text { LDL } \\
\text { level (mg/dl) }\end{array}$ & $\begin{array}{c}\text { HDL } \\
\text { level (mg/dl) }\end{array}$ & $\begin{array}{c}\text { Atherogenic } \\
\text { index }\end{array}$ \\
\hline $\begin{array}{l}\text { Normal saline } \\
1 \mathrm{ml} / \text { animal }\end{array}$ & $81.54 \pm 2.99$ & $74.04 \pm 2.97$ & $14.81 \pm 0.59$ & $23.25 \pm 3.56$ & $48.58 \pm 1.327$ & $0.68 \pm 0.08$ \\
\hline $\begin{array}{l}\text { Triton only } \\
200 \quad\end{array}$ & $120.9 \pm 2.82^{\# \# \#}$ & $132.3 \pm 2.57^{\# \# \#}$ & $26.47 \pm 0.51^{\# \# \#}$ & $71.51 \pm 2.16^{\# \# \#}$ & $41.12 \pm 1.58^{\# \#}$ & $1.95 \pm 0.09^{\# \#}$ \\
\hline $\begin{array}{l}\text { Simvastatin } \\
\text { 4+ TWR }\end{array}$ & $84.79 \pm 2.63^{* *}$ & $92.63 \pm 2.94^{\star *}$ & $18.53 \pm 0.58^{\star *}$ & $26.70 \pm 2.86^{\star *}$ & $48.41 \pm 0.914^{\star *}$ & $0.75 \pm 0.06^{* *}$ \\
\hline $\begin{array}{l}\text { Et-PCF } \\
200+\text { TWR }\end{array}$ & $109.7 \pm 2.82^{*}$ & $121.9 \pm 3.79$ & $24.39 \pm 0.75$ & $60.50 \pm 3.29^{*}$ & $41.04 \pm 1.63$ & $1.69 \pm 0.13$ \\
\hline $\begin{array}{l}\text { Et-PCF } \\
400+\text { +TWR }\end{array}$ & $101.9 \pm 2.73^{* *}$ & $107.4 \pm 1.84^{\star *}$ & $21.47 \pm 0.36^{\star *}$ & $53.04 \pm 1.61^{* *}$ & $40.70 \pm 1.41$ & $1.50 \pm 0.04^{* *}$ \\
\hline $\begin{array}{l}\text { Et-PCF } \\
600+T W R\end{array}$ & $88.55 \pm 2.68^{* *}$ & $97.15 \pm 2.65^{\star \star}$ & $19.43 \pm 0.53^{\star \star}$ & $32.77 \pm 2.96^{\star *}$ & $46.48 \pm 1.25^{\star}$ & $0.91 \pm 0.07^{* *}$ \\
\hline
\end{tabular}

Values are expressed as mean \pm SEM $(n=6)$; data were analyzed by one-way ANOVA followed by Dunnet's test; ${ }^{\#}$ denotes compared to normal control group, ${ }^{*} p<0.01=$ very significant; ${ }^{* *} p<0.05=$ significant, compared with triton-treated rats (Group II)

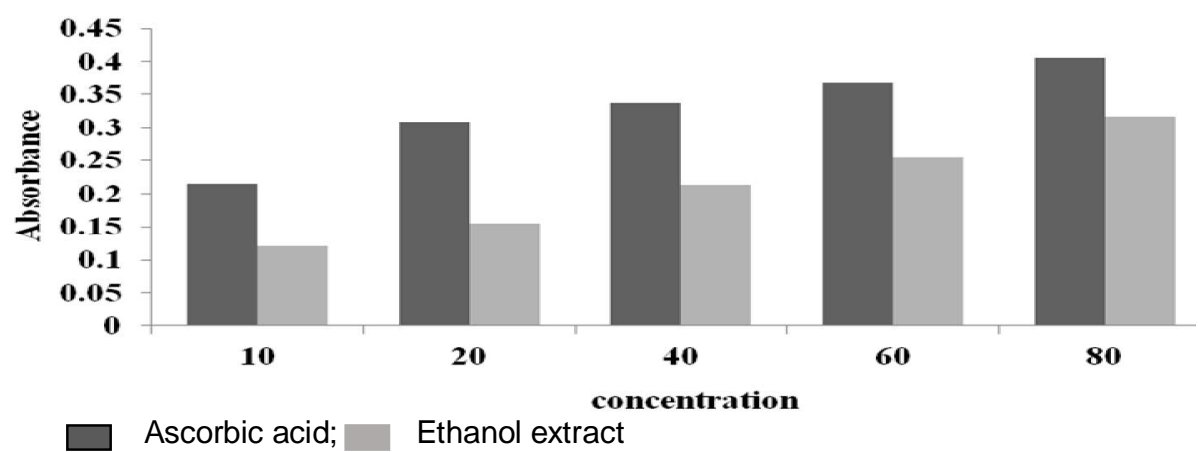

Fig 3: Effect of Prosopis cineraria on in-vitro reducing power assay 


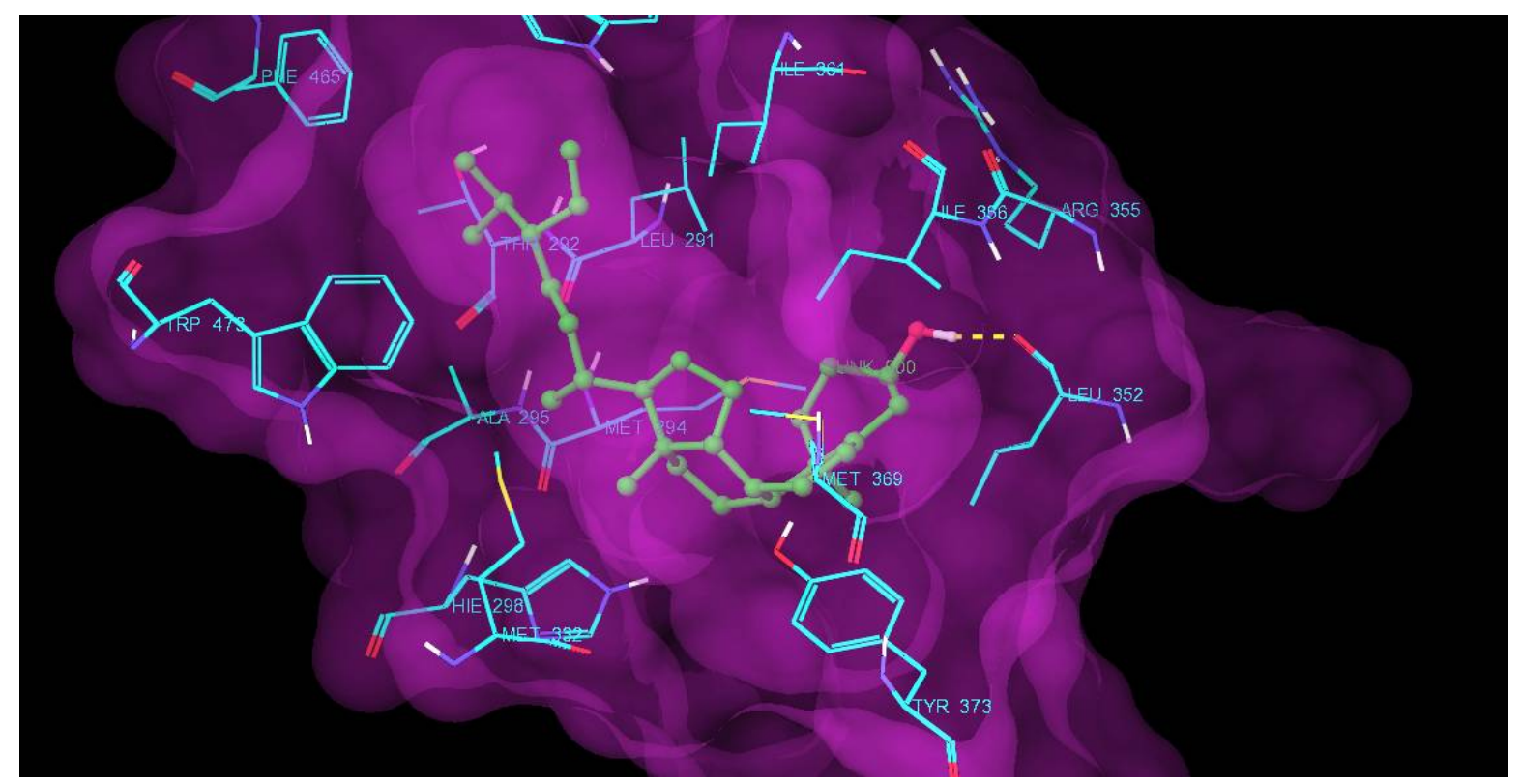

Fig 4: Binding mode of $\boldsymbol{\beta}$-sitosterol in the FXR binding pocket (PDB: $10 \mathrm{OSH}$ ) where $\boldsymbol{\beta}$-sitosterol shows $\mathrm{H}$-bond interaction between hydrogen of hydroxyl group and oxygen of LEU-352 amino acid

\section{Molecular docking data}

$\beta$-Sitostirol was subjected for molecular docking by calculating the minimum energy to activate the target receptor FXR, an important regulatory macromolecule whose activation promotes hypolipidemic activity. The protein structure file (PDB ID: 1OSH) was taken from PDB (www.rcsb.org/pdb) and showed the Binding mode of $\beta$-sitosterol in the FXR binding pocket in Fig 4.

\section{DISCUSSION}

In the present study, the effect of the ethanolic extract of Prosopis cineraria on experimentallyinduced hyperlipidemia was evaluated in rats. In acute oral toxicity study, $70 \%$ ethanolic extract of Prosopis cineraria up to the oral dose of 5000 $\mathrm{mg} / \mathrm{kg}$ body weight did not produce signs of toxicity or mortality in rats. Hence 1/10th of this dose was selected as an effective evaluation dose $(500 \mathrm{mg} / \mathrm{kg})$. Triton WR-1339 is a non-ionic detergent and has been widely used to induce an acute hyperlipidemia in experimental animals [26]. The possible mechanism of action of triton is to block the clearance of triglyceride-rich lipoproteins by inhibiting the lipoprotein lipase [27]. In the present study, the highest levels of plasma triglycerides and total cholesterol were reached after $24 \mathrm{~h}$ triton administration compared to normal control group. Also, there were increase levels of VLDL and LDL along with rise in atherogenic index as compared to normal control group.
Elevated level of blood cholesterol especially LDL-C is a known major risk factor for CHD whereas HDL-C is cardio protective [6]. Treatment with the extract significantly decreased the levels of total cholesterol and LDL-C compared to the Triton treated (hyperlipdemic) group. Extract treated group also showed remarkable reduction in triglyceride and VLDL cholesterol compared to triton treated group. Hypolipidemic effect of extract increases with increase in dose levels. At the highest dose levels of $400 \mathrm{mg} / \mathrm{dl}$ and $600 \mathrm{mg} / \mathrm{dl}$ hypolipidemic effect of extract is almost equivalent to standard drug simvastatin. Atherogenic index indicates the deposition of foam cells or plaque or fatty infiltration or lipids in the heart, coronaries, aorta, liver and kidneys. The higher the atherogenic index, the higher the risk of oxidative damage to these organs [28]. This atherogenic index was significantly reduced in the Prosopis cineraria treated groups compared to triton control group. The reduction in atherogenic index at the highest dose of extract is almost equal to standard drug simvastatin. This may be attributable to plant sterols that inhibit the absorption of dietary cholesterol and reduce atherogenic index. But the resulting decrease in serum cholesterol has been slight [9]. Although Prosopis cineraria have been shown to contain $\beta$-sitosterol using the HPLC, $\beta$-sitosterol is a plant sterol with a structure similar to that of cholesterol, except for the substitution of an ethyl group at C24 of its side chain. The cholesterol lowering effect may be due to this inhibition in reabsorption of cholesterol from endogenous sources in association with a simultaneous increase in its 
excretion into feces in the form of neutral steroids. Since the results of the study indicated that extract has beneficial effect on lipid profile.

The findings of the present study also showed that the fruit extract of Prosopis cineraria possesses strong free radical scavenging and antioxidant activity. Polyphenols other than vitamin $\mathrm{E}$ have been known to exert powerful antioxidant effect in vitro. They inhibit lipid peroxidation by acting as chain-breaking peroxylradical scavengers, and can protect LDL from oxidation. Phytochemical investigation revealed the presence of polyphenols, thus the antioxidant effects could be due to presence of these phenolic components in the extract [10].

Further docking study was carried out for the target compounds into FXR using GLIDE (Schordinger Inc., USA). The crystal structure of the enzyme with Fexaramine (PDB: 1OSH) was obtained from protein data bank PDB. Our compounds were modeled by positioning them in the co-crystallized ligand Fexaramine binding site in accordance with the published crystal structures.

The entire complex was then subjected to alternate cycles of minimization and dynamics. The intent was to get a satisfactory structure for the complex that was consistent with the published crystal structure. From the comparative docking study of our compounds with Fexaramine lead compounds we could observe how our compounds might bind to the FXR binding site, based on the knowledge of the structure of similar active sites. We redocked Fexaramine into the active site of the enzyme and then we replaced with our compounds in order to compare the binding mode of both cocrystallized ligand and the test compound. These docking studies have revealed that the betasitosterol shows $\mathrm{H}$-bonding with Leu-352 amino acid backbone with glide score of $-8.32 \mathrm{kcal} / \mathrm{mol}$. These interactions underscore the importance of oxygen as hydrogen bond acceptor for binding and the subsequent agonistic capacity. The results of this virtual screening support the postulation that the active compounds possibly binds on the same enzyme target where Fexaramine binds.

\section{CONCLUSION}

The fruits of Prosopis cineraria can be used in the treatment of hyperlipidemia which is one of the major causes of cardiovascular disease, and may serve as a substitute to currently used hypolipidemic drugs in the therapy of hyperlipidemia. However, long-term studies are required to determine the adverse and beneficial effects of the isolated phytoconstituent.

\section{REFERENCES}

1. WHO Monica project, Tunstall-Pedoe $H$, Kuulasmaa $K$, Amouyel $P$, Arveiler $D$, Rajakangas A, Pajak $A$. Myocardial infarction and coronary deaths in the World Health Organisation Project. Circulation 1994; 90: 583-612.

2. Bennani-Kabchi $N$, Fdhil $H$, Cherrah $Y$, Kehel $L$, el Bouavadi F, Amarti A, Saidi M, Marquie G. Effects of Olea europea var. oleaster leaves in hypercholesterolemic insulin-resistant sand rats. Therapie 1999; 54(6): 717-723.

3. Berliner JA, Heinecke JW. The role of oxidized lipoproteins in atherogenesis. Free Radical Biol. Med 1996; 20: 707-727.

4. Gingliano D. Dietary antioxidants for cardiovascular prevention. Nutr Metab Cardiovasc. Dis 2000; 10: 3844.

5. Anderson JK, Teuber SS, Gobeille A, Cremin $P$, Waterhouse AL, Steinberg FM. Walnut polyphenolics inhibit in vitro human plasma and $L D L$ oxidation. $J$ Nutr 2000; 131: 2837-2842.

6. Rohilla A, Dagar N, Rohilla S, Dahiya A, Kushnoor A. Hyperlipidemia -a deadly pathological condition. Int $J$ Curr Pharm Res 2012; 4: 15-18.

7. Hemalatha S, Wahi AK, Singh PN, Chansouria JPN. Hypolipidemic Activity of Aqueous Extract of Withania coagulans Dunal in Albino Rats. Phytother Res 2006; 20: 614-617.

8. Umamaheswari $M$, Asokkumar $K$, Rathidevi $R$, Sivashanmugam AT, Subhadradevi $V$, Ravi TK. Antiulcer and in vitro antioxidant activities of Jasminum grandiflorum L. J Ethnopharmacol 2007; 110: 464-470.

9. Jain PG, Patil SD, Haswani NG, Girase MV, Surana SJ. Hypolipidemic activity of Moringa oleifera Lam., Moringaceae, on high fat diet induced hyperlipidemia in albino rats. Revista Brasileira de Farmacognosia 2010; 20(6): 969-973.

10. Pilaipark C, Panya K, Yupin S, Srichan P, Noppawan PM, Laddawal PN, Piyanee $R$, Supath $S$ and Klaiupsorn $S P$. The in vitro and ex vivo antioxidant properties, hypolipidaemic and antiatherosclerotic activities of water extract of Moringa oleifera Lam. Leaves. J. Ethnopharmacol 2008; 116: 439-446.

11. Burkart A. A monograph of genus Prosopis (Leguminous). J Ar Arb 1976; 57: 219-49, 450-525.

12. Shalini. Vedic Leguminous Plants, (Shalini, Ed), Classical publishing co, 1997; pp. 57-80.

13. Toky OP. Medicinal values of Prosopis cineraria in arid and semiarid India. Society of Chemical Industry, I, 1999; pp 1-10.

14. Purohit SD, Ramawat KG, Arya HC. Phenolics, peroxidase and phenolase as related to gall formation in some arid zone plants. Curr Sci 1979; 48: 714-716.

Trop J Pharm Res, September 2015; 14(9): 1627 
15. Rhoades DF. Herbivores, their interaction with secondary plant metabolites. Acad. Press Inc. London, 1979; pp 3-54.

16. Nahla AH and Farag WT. Design, synthesis and docking studies of new furobenzopyranones and pyranobenzopyranones as photo-reagent towards DNA and as antimicrobial agents. Eur. J. Med. Chem 2010; 45: 317-325.

17. Kokate CK. Practical Pharmacognosy. Vallabh Prakashan, New Delhi, India, 1998; 107-111.

18. Guidance document on acute oral toxicity testing. Series on testing and assessment NO 24.OECD environment, health and safety publications 2001.Accessed from http://www.oecd.org/officialdocuments/publicdisplayd ocumentpdf/?cote $=e n v / j m / m o n o(2001) 4 \&$ doclanguag $e=e n$ on 18 June 2013.

19. Kourounakis AP, Victoratos $P$, Peroulis N, Stefanou, Yiangou $M$, Hadjipetrou $L$. Experimental Hyperlipidemic and the Effect of NSAIDs. Exper Mol Pathol 2002; 73: 135-138.

20. Friedewald WT, Levy RI, Frederickson DS. Estimation of the concentration of low density lipoprotein cholesterol in plasma, without use of preparative ultracentrifuge. Clin chem. 1972; 18: 499-502.

21. Muruganandan S, Srivinasan K, Gupta S, Gupta PK, Lal $J$. Effect of mangiferin on hyperglycemia and atherogenicity in streptozotocin diabetic rats. $J$ Ethnopharmacol 2005; 97: 497-501.

22. Oyaizu M. Studies on products of browing reaction prepared from glucosamine: Jap J Nutri 1986; 44: 307-315.

23. http://www.rcsb.org/pdb/explore.do?structureld=1OSH. Accessed on 23rd October 2013.

24. Zhong H, Tran LM, Stang JL. Induced-fit docking studies of the active and inactive states of protein tyrosine kinases. J. Mol. Graph. Mod 2009; 28: 336-346.

25. Shimazaki H. Antioxidants. In: Niki E, Shimazaki, $H$, Mino, $M$ (eds). Free radicals and biological defense: Japanese Science Societies Press, Tokyo, 1994; pp 45-57.

26. Bertges LC, Mourăo Jr CA, Souza JB, Cardoso VA. Hyperlipidemia induced by triton WR 1339 (Tyloxapol) in wistar rats. Rev Bras Cien Med Saūde 2011; 1: 32-34.

27. Otway S, Robinson DS. The use of a non-ionic detergent (triton WR 1339) to determine rates of triglyceride entry into the circulation of the rat under different physiological conditions. J.Physiol 1967; 190: 321 332.

28. Saluja MP, Kapil RS, Popli SP. Studies in medicinal plants: part VI. Chemical constituents of Moringa oleifera Lam. (hybrid variety) and isolation of 4hydroxymellein. Indian J Chem B 1978; 16B: 10441045. 